\title{
IRRIGATION DEPTHS AND YIELD RESPONSE FACTOR IN THE PRODUCTIVE PHASE OF YELLOW MELON ${ }^{1}$
}

\author{
BENITO MOREIRA DE AZEVEDO ${ }^{2}$, GUILHERME VIEIRA DO BOMFIM ${ }^{2}$, \\ JOAQUIM RAIMUNDO DO NASCIMENTO NETO ${ }^{3}$, THALES VINÍCIUS DE ARAÚJO VIANA ${ }^{2}$, \\ DENISE VIEIRA VASCONCELOS ${ }^{2}$
}

ABSTRACT - Local knowledge about irrigation management in yellow melon can promote higher precision to water supply for irrigation purposes, increasing productivity and reducing production costs. The aim of this study was to evaluate the effects of different irrigation depths for yellow melon production and on yield response factor to water (Ky) in the productive phase. The experiment was carried out in Fortaleza, state of Ceará, Brazil, in complete randomized blocks with six treatments, four replicates and six plants per plot. Treatments were applied from intermediate (III) to final (IV) physiological state with water depths equivalents to $25 \%, 50 \%, 75 \%, 100 \%, 125 \%$ and $150 \%$ of the crop evapotranspiration (ETc). Ky was calculated according to FAO-33 report methodology in the range from $25 \%$ to $100 \%$ ETc. The variables analyzed were number of fruits per plant, polar and equatorial diameters, fruit fresh weight, commercial yield, skin and pulp thickness, and soluble solids. Treatments influenced the number of fruits per plant, equatorial diameter, fruit fresh weight, commercial yield, and soluble solids. The best results were reached with commercial yield equal to $32.2 \mathrm{Mg} \mathrm{ha}^{-1}, 1.46$ fruits per plant, equatorial diameter equal to $16.3 \mathrm{~cm}$, fruit fresh weight equal to $2.3 \mathrm{~kg}$ and soluble solids equal to $12{ }^{\circ} \mathrm{Brix}$ with $100.3 \% \mathrm{ETc}$ in the productive phase. The crop was tolerant to water supply reduction on the productive phase $(\mathrm{Ky}<1)$ through daily irrigation with controlled water deficit.

Index terms: Cucumis melo, evapotranspiration, drip irrigation.

\section{PRODUÇÃO E FATOR DE RESPOSTA DO MELOEIRO AMARELO A LÂMINAS DE IRRIGAÇÃO NA FASE PRODUTIVA}

\begin{abstract}
RESUMO - Informações locais sobre manejo hídrico em olerícolas podem oferecer maior precisão ao fornecimento de água pela irrigação, concorrendo para elevar a produtividade e reduzir os custos. Neste trabalho, foram avaliados os efeitos de distintos níveis de irrigação sobre a produção do melão-amarelo e sobre o fator de resposta da cultura frente à irrigação deficitária $(\mathrm{Ky})$. $\mathrm{O}$ experimento foi conduzido em Fortaleza, Ceará, utilizando o delineamento em blocos casualizados, com seis tratamentos, quatro repetições e parcelas de seis plantas. Os tratamentos foram diferenciados nas fases fenológicas intermediária (III) e final (IV), com lâminas de água correspondentes a 25\%, 50\%, 75\%, 100\%, 125\% e 150\% da evapotranspiração da cultura (ETc). O Ky foi estimado pela metodologia do Boletim 33 da FAO, no intervalo de $25 \%$ a $100 \%$ da ETc. Foram analisadas as variáveis número de frutos por planta, diâmetros polar e equatorial, massa fresca do fruto, produtividade comercial, espessuras da casca e da polpa e sólidos solúveis. Os tratamentos influenciaram significativamente sobre o número de frutos por planta, o diâmetro equatorial, a massa fresca do fruto, a produtividade comercial e os sólidos solúveis. As irrigações com 100,3\% da ETc na fase produtiva do meloeiro maximizaram a produtividade comercial, estimada em $32,2 \mathrm{Mg} \mathrm{ha}^{-1}$ e proporcionaram 1,46 fruto por planta com diâmetro equatorial de $16,3 \mathrm{~cm}$, massa fresca de $2,3 \mathrm{~kg}$ e sólidos solúveis de $12^{\circ} \mathrm{Brix}$. A cultura mostrou-se tolerante à redução do suprimento de água na fase produtiva $(\mathrm{Ky}<1)$ com a adoção, da irrigação diária com déficit hídrico controlado.
\end{abstract}

Termos para indexação: Cucumis melo, evapotranspiração, gotejamento.

${ }^{1}$ (Paper 118-15). Received May 11, 2015. Accepted February 25, 2016.

${ }^{2}$ Phd in Agricultural Engineering, from Federal University of Ceará, Agricultural Engineering Department, Fortaleza, Ceará, Brazil, Dom José Lourenço Street, Campus do Pici, Bloco 804, Mailbox: 12.168, Zip code: 60.450-760, E-mails: benitoazevedo@hotmail.com; guile2007@gmail.com, thales@ufc.br; denisevasconcelos@hotmail.com

${ }^{3}$ Master in Agricultural Engineering from Federal University of Ceará, Agricultural Engineering Department, Fortaleza, Ceará, Brazil. Dom José Lourenço, Campus do Pici, Bloco 804, Mailbox: 12.168, Zip code: 60.450-760, E-mail: netoparaguai456@yahoo.com.br 


\section{INTRODUCTION}

Yellow melon (Cucumis melo L.) is the main horticulture exported by the state of Ceará (CAMPELO et al., 2014). Regarding irrigation, water depth quantification is a fundamental parameter, since crop production can be impaired by water deficit or excess. Water deficit reduces the number of fruits (Mani, 2014), commercial productivity (PIRES et al., 2013), size, fresh weight (CAVALCANTI et al., 2015) and soluble solids (BAHADUR et al., 2011) of fruits. Water excess reduces size, fresh weight (CAVALCANTI et al., 2015) and soluble solids (SUASSUNA et al., 2011) of fruits, favors the loss of water and soil nutrients beyond the root zone (PIRES et al., 2013, FIGUEIRÊDO et al., 2014), increasing production costs.

In the melon cycle, the fruiting period, which goes from fruit fixation to maturation, is the period in which the highest water consumption occurs, and is therefore the most critical for irrigation. During this phase, problems related to irrigation management or to difficult-to-control climatic factors (excessive rains or prolonged droughts) may result in water stress and therefore may be decisive for crop production.

Experiments with water depths applied throughout the melon cycle (AL-MEFLEH et al., 2012; CAVALCANTI et al., 2015) or in part of it (SIMSEK; COMLEKCIOGLU, 2011) have shown distinct results. This divergence stems, among other factors, from irrigation management, the phenological phase of the crop and the edaphoclimatic variations of each region. This fact makes its generalization to other regions difficult and ratifies the relevance of local trials (PEREIRA FILHO et al., 2014; VALNIR JÚNIOR et al., 2013).

In northeastern Brazil, due to the fact that there are marked rainfall irregularities and scarcity of water resources, the irrigation strategy must take into account possible deficient water supply to plants at any stage of plant cycle. In this context, knowledge of crop sensitivity to stress due to water deficiency is fundamental to reduce impacts on production (MIORINI et al., 2011) and on irrigation costs (ALI et al., 2007). Experiments addressing this theme have shown positive results regarding melon tolerance to stress due to water scarcity (DOGAN et al., 2008; SHARMA et al., 2014).

The crop response factor $(\mathrm{Ky})$ is the coefficient used to indicate plant sensitivity to water deficit at any stage of its cycle. For this reason, it is often used in irrigation management. Bulletins 33 (DOORENBOS; KASSAM, 1979) and 66 (STEDUTO et al., 2012) of the United Nations Organization for Food and Agriculture do not have information on Ky for yellow melon. The few existing information (LEITE et al., 2014; SIMSEK; COMLEKCIOGLU, 2011), although coinciding in the classification issue for indicating low crop sensitivity to water scarcity, greatly differs in numerical terms. This difference may come from regional diversity and management as well as from the phases evaluated (each one or all of them). Silva et al. (2014) explain that the discrepancy between Ky values in experiments is quite common in the most diverse cultures and conditions, and Steduto et al. (2012) recommend their experimental estimation under local conditions.

Due to the scarcity of information on irrigation of yellow melon during the productive period, intermediate (III) and final (IV) phenological phases, this study aimed to evaluate the effects of irrigation on fruit production and on the response factor $(\mathrm{Ky})$ to controlled deficit irrigation under the edaphoclimatic conditions of the coast of Ceará.

\section{MATERIAL AND METHODS}

The work was carried out between October 23, 2009 and December 28, 2009 in the experimental area of the Federal University of Ceará, Fortaleza, Ceará ( $3^{\circ} 44^{~ ' S}, 38^{\circ} 33^{\prime} \mathrm{W}$ and $19.50 \mathrm{~m}$ asl).

According to the Köppen classification, the climate of the region is Aw' type, tropical rainy, tropical savannah, with the driest period in the winter season and maximum rainfall in summer-fall. The data of the main agrometeorological variables during the experiment were representative of the region, since between the daily values of reference evapotranspiration estimated during the year 2009 and the estimated daily averages of a series of ten years, from 2001 to 2010, there was no difference at $5 \%$ probability by the Student's t-test (Figure 1).

The physicochemical characteristics of the Red-Yellow Argisol (SANTOS et al., 2006) in the $0.20 \mathrm{~m}$ layer were: fine sand $\left(451 \mathrm{~g} \mathrm{~kg}^{-1}\right)$; coarse sand $\left(364 \mathrm{~g} \mathrm{~kg}^{-1}\right)$; silt $\left(122 \mathrm{~g} \mathrm{~kg}^{-1}\right)$; clay $\left(63 \mathrm{~g} \mathrm{~kg}^{-1}\right)$; natural clay $\left(63 \mathrm{~g} \mathrm{~kg}^{-1}\right)$; specific weight $\left(1.47 \mathrm{~g} \mathrm{~cm}^{-3}\right)$;

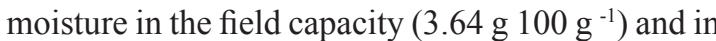

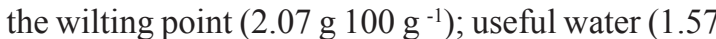

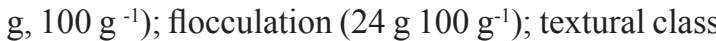
(sand); $\mathrm{K}+\left(92 \mathrm{mg} \mathrm{dm}^{-3}\right) ; \mathrm{Na}-\left(39 \mathrm{mg} \mathrm{dm}^{-3}\right) ; \mathrm{Ca}^{2+}$ $\left(1.7 \mathrm{cmolc} \mathrm{dm}^{-3}\right) ; \mathrm{Mg}^{2+}\left(1.4 \mathrm{cmolc} \mathrm{dm}^{-3}\right) ; \mathrm{Al}^{3+}(0.05$ cmolc dm $\left.{ }^{-3}\right) ; \mathrm{PH}_{1: 0.25}(5.6) ; \mathrm{CE}\left(0.49 \mathrm{dS} \mathrm{m}^{-1}\right)$.

The irrigation system used was the surface drip type composed of drip tapes with integrated 
and non-self-compensating emitters (Azudline ${ }^{\circledR}$ model 160). Drip tapes were distributed in the field according to the spacing adopted for yellow melon, of $2.0 \mathrm{~m}$ between rows and $0.5 \mathrm{~m}$ between plants. Irrigation was carried out with one emitter per plant, with mean flow rate of $1.30 \mathrm{~L} \mathrm{~h}^{-1}$ at $75 \mathrm{kPa}$ nominal pressure and application intensity of $1.3 \mathrm{~mm} \mathrm{~h}^{-1}$.

Hybrid 'Gold Mine' yellow melon was sown on October 23, 2009 on styrofoam trays containing Hortimix ${ }^{\circledR}$ substrate and kept in a screen that allowed $50 \%$ shading for adequate germination. On October 28, 2009, when properly developed and uniform, seedlings were transplanted to beds (or ridges) of $3.0 \mathrm{~m} \times 1.0 \mathrm{~m} \times 0.20 \mathrm{~m}$, which were manually raised with the soil of the arable layer according to the crop spacing. These beds were constructed with the purpose of improving the distribution of water applied near the root system of the plants.

A complete randomized block design with six treatments and four replicates was used. The plots of each treatment had four useful plants, because the first and the last plants were considered border plants. There were no borders plants between rows, since the spacing adopted, together with the survey of beds, did not allow interference between treatments. These were differentiated in the productive phase, phenological stages III and IV of yellow melon, with water depths referring to $25,50,75,100,125$ and $150 \%$ crop evapotranspiration (ETc) applied at different irrigation times.

Irrigation management was based on simplified climatological water balance for the $24 \mathrm{~h}$ period (Equation 1).

$$
\mathrm{LL}=\mathrm{ETc}-\mathrm{Pe}
$$

where:

LL is the liquid irrigation depth (mm day $\left.{ }^{-1}\right)$;

ETc is the crop evapotranspiration $\left(\mathrm{mm} \mathrm{day}^{-1}\right)$ of each treatment (Equation 2); and

$\mathrm{Pe}$ is the effective rainfall $\left(\mathrm{mm} \mathrm{day}^{-1}\right)$.

$$
\mathrm{ETc}=\mathrm{EToPM} \mathrm{Kc} \mathrm{Kr}
$$

where:

EToPM is the reference evapotranspiration of Penman-Monteith $\left(\mathrm{mm} \mathrm{day}^{-1}\right)$;

$\mathrm{Kc}$ is the cultivation coefficient (dimensionless); and $\mathrm{Kr}$ is the coverage coefficient (dimensionless).

Pe, estimated according to Smith (1992), when above ETc, was considered excess water and, therefore, was not accumulated for irrigation on the following day $(\mathrm{Pe} \leq \mathrm{ETc})$. EToPM was estimated according to Allen et al. (2006), with daily data from an automated weather station near the experimental area. Kc, adopted by Miranda and Bleicher (2001), was 0.21 in phase I; from 0.21 to 1.21 in phase II (interpolated); 1.21 in phase III; and from 1.21 to 0.98 in phase IV (interpolated). $\mathrm{Kr}$ was estimated according to Keller and Karmeli (1974), with the coverage factor of $10 \%$ up to 21 days after sowing (DAS), from 10 to $100 \%$ (interpolated) up to 40 DAS and $100 \%$ up to 66 DAS.

The crude irrigation depth was calculated by Equation 3, disregarding the need for leaching (leaching ratio less than 0.1 ).

$$
\mathrm{LB}=\mathrm{LL}\left(\frac{\mathrm{TR}}{\mathrm{EF}}\right)
$$

where:

LB is the crude irrigation depth $\left(\mathrm{mm} \mathrm{day}^{-1}\right)$;

RT the irrigation shift (1 day); and

$\mathrm{EF}$ is the water application efficiency (\%).

EF of $85.5 \%$ was estimated with the product of uniformity coefficients of Christiansen (estimated in the experimental area at 0.95 ) and soil transmissivity (tabulated at 0.90) for arid climate, sandy texture soil and root depth less than $0.75 \mathrm{~m}$, both determined by the methodology of Keller and Karmeli (1974).

The irrigation time was calculated by means of Equation 4.

$$
\mathrm{Ti}=\left(\frac{\mathrm{LB} A}{\mathrm{Q}_{\mathrm{e}} \mathrm{N}_{\mathrm{ep}}}\right)
$$

where:

$\mathrm{Ti}$ is the irrigation time (h);

A is the area per plant $\left(1 \mathrm{~m}^{2}\right)$;

Qe is the emitter flow $\left(1.3 \mathrm{~L} \mathrm{~h}^{-1}\right)$; and

$\mathrm{N}_{\text {ep }}$ is the number of emitters per plant (1).

The total water depth used to meet the water needs of yellow melon resulted from the sum of effective precipitation and liquid irrigation depth, since the crude irrigation depth only ensured its adequate application.

The water supply in the initial $(I=22$ days $)$ and growth phenological phases (II $=18$ days) was based on $100 \%$ ETc. On trays, from sowing to transplanting (23/10/2009 to 28/10/2009), seedlings were irrigated four times a day via hand sprayer with $5 \mathrm{~mm}$ of water. In the field, from transplanting to the end of the vegetative growth $(28 / 10 / 2009$ to $01 / 12 / 2009$ ), plants received a total water depth of $31.4 \mathrm{~mm}$.

Treatments were differentiated in the productive period, phenological stages III and IV $(12 / 02 / 2009$ to $12 / 28 / 2009)$, with total depths 
corresponding to $25 \%, 50 \%, 75 \%, 100 \%, 125 \%$ and $150 \%$ ETc (Table 1).

The daily depths of each treatment were graphically compared with the available water capacity (CAD) and with the readily available water (AFD) in the soil to verify if plants were submitted to water stress conditions. CAD was calculated (CAD $=[(\mathrm{cc}-\mathrm{pmp}) / 10] \mathrm{zd})$ at $6.92 \mathrm{~mm}$, with gravimetric moisture data in the field capacity $(\mathrm{cc}=3.64 \mathrm{~g} 100$

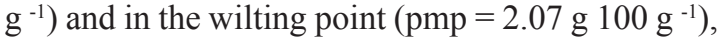
the effective root depth $(\mathrm{z}=30 \mathrm{~cm})$ and the specific weight $(\mathrm{d}=1.47 \mathrm{~g} \mathrm{~cm}-3)$. AFD was daily estimated $(\mathrm{AFD}=\mathrm{CAD} p)$ with depletion factor ' $p$ ' of yellow melon corrected for daily ETc, as proposed in the FAO Bulletin $56(\mathrm{p}=0.45+0,04(5-\mathrm{ETc}))$ by Allen et al. (2006).

Fertilization was carried out via fertigation with the following fertilizers: urea and calcium nitrate (120 kg ha ${ }^{-1} \mathrm{~N}$ and $64.8 \mathrm{~kg} \mathrm{ha}^{-1} \mathrm{Ca}$ ); phosphoric acid $\left(240 \mathrm{~kg} \mathrm{ha}^{-1} \mathrm{P}\right)$; white potassium chloride $\left(180 \mathrm{~kg} \mathrm{ha}^{-1}\right.$ $\left.\mathrm{K}_{2} \mathrm{O}\right)$; magnesium sulfate $\left(21.6 \mathrm{~kg} \mathrm{ha}^{-1} \mathrm{Mg}\right)$; boric acid $\left(1 \mathrm{~g} \mathrm{plant}^{-1} \mathrm{Bo}\right)$; zinc sulfate $\left(2 \mathrm{~g} \mathrm{plant}^{-1} \mathrm{Zn}\right)$. Fertilizers were weekly applied by fertigation $(5,12$, $19,26,33,40,47,54$ and 61 days after sowing) with the same volume to maintain application uniformity in all plants. In the differentiation of treatments and only at 54 days after sowing, this management showed the need for irrigation of treatments $25 \%$ and $50 \%$ ETc, although Pe was above ETc. In this case, and because the excess water volume applied by fertigation was very low, it was not considered as liquid irrigation depth.

Treatments were manual weeding, spraying with insecticides and fungicides, branching, fruit turning and harvest (66 and 69 days after sowing). Only commercial fruits, in this case, those of intense yellow color with fresh weight between 0.60 and $2.80 \mathrm{~kg}$, free of diseases and physical injuries, were harvested.

The variables analyzed were: number of fruits per plant, polar and equatorial diameters, fresh fruit weight, commercial productivity, skin and pulp thickness and soluble solids. In the analysis of polar and equatorial diameters, fresh fruit weight and commercial productivity, all commercial fruits from the useful area of plots were used. In the examination of skin and pulp thickness and soluble solids, two fruits from each plot were randomly selected.

The number of fruits per plant was obtained by the ratio between the total fruits produced in the useful area and the total plants in the respective useful area of each plot. The fresh weight of fruits was obtained with a precision electronic scale $(0.01$ $\mathrm{g}$ resolution), calculating the arithmetic mean for each plot. Commercial productivity was estimated from the fresh weight of fruits of plots for the area of one hectare. Polar (fruit length) and equatorial (fruit width) diameters were measured with a digital caliper ( $0.01 \mathrm{~mm}$ resolution), calculating the arithmetic mean for each plot. Using two fruits of each plot, skin and pulp thickness was measured using the caliper above, as well as soluble solids, with a portable digital refractometer $(0.1 \%$ resolution $)$. The mean data of variables were submitted to regression analysis of variance by the orthogonal polynomial method, testing linear and quadratic models.

Water productivity or water use efficiency in the productive phase was calculated by means of Equation 5.

$$
\mathrm{WUE}=\frac{\mathrm{Y}}{\mathrm{W}}
$$

where:

EUA is the water use efficiency $\left(\mathrm{Mg} \mathrm{ha}^{-1} \mathrm{~mm}^{-1}\right)$;

$\mathrm{Y}$ the commercial yield $\left(\mathrm{Mg} \mathrm{ha}^{-1}\right)$; and

$\mathrm{W}$ is the total water depth in the productive phase $(\mathrm{mm})$.

The response factor of yellow melon in the productive phase was calculated according to Equation 6 (DOORENBOS; KASSAM, 1979).

$$
\left(1-\frac{\mathrm{Yr}}{\mathrm{Ym}}\right)=\mathrm{Ky}\left(1-\frac{\mathrm{ETr}}{\mathrm{ETm}}\right)
$$

where:

Ky is the crop response factor (dimensionless);

$\mathrm{Yr}$ is the actual yield $\left(\mathrm{Mg} \mathrm{ha}^{-1}\right)$;

$\mathrm{Ym}$ is the maximum yield $\left(\mathrm{Mg} \mathrm{ha}^{-1}\right)$;

$\mathrm{ETr}$ is the actual evapotranspiration in the productive phase ( $\mathrm{mm})$; and

$\mathrm{ETm}$ is the maximum evapotranspiration in the productive phase $(\mathrm{mm})$.

The evapotranspiration data used in Equation 6 were adapted, since the actual ETr and ETm values were not measured. Therefore, to estimate $\mathrm{Ky}$, it was assumed that the maximum evapotranspiration values were estimated with $100 \%$ ETc treatment, and the actual values were estimated with $25 \%, 50 \%$ and $75 \%$ ETc treatments.

After calculating the individual Ky values for the interval of this experiment ( $25 \%$ to $100 \%$ ETc), Ky values were estimated for the interval proposed by FAO Bulletin 33 ( $50 \%$ to $100 \%$ ETc). To compose this interval, deficits of $50 \%, 60 \%, 70 \%, 80 \%$ and $90 \%$ ETc were selected. The corresponding total water depth and commercial yield values were estimated based on the polynomial regression equation obtained with the real commercial productivity $v s . \%$ ETc data 
for $25 \%, 50 \%, 75 \%, 100 \%, 125 \%$ and $150 \%$ ETc treatments. The maximum values (ETm and $\mathrm{Ym}$ ) were considered as those of the optimal water depth estimated with this equation, and the actual values (ETr and $\mathrm{Yr}$ ), as those estimated with percentages of $50 \%, 60 \%, 70 \%, 80 \%$ and $90 \%$ ETc .

The absolute Ky value for the entire deficit interval was considered as the angular coefficient of the regression equation, adjusted by the origin, between the relative yield drop $(1-\mathrm{Yr} / \mathrm{Ym})$ and the relative evapotranspiration deficit $(1-\mathrm{ETr} / \mathrm{ETm})$ (BILIBIO et al., 2010).

The sensitivity of the melon crop to water supply deficit was classified according to FAO Bulletins 33 (DOORENBOS; KASSAM, 1979) and 66 (STEDUTO et al., 2012). According to FAO Bulletin 33, the crop may have 'low' sensitivity (Ky $<0.85)$, 'low-intermediate' sensitivity $(0.85<\mathrm{Ky}$ $<1.00)$, 'intermediate-high' sensitivity $(1.00<\mathrm{Ky}<$ $1.15)$ and 'high' sensitivity (Ky>1.15). According to FAO Bulletin 66, the crop can be 'very sensitive' $(\mathrm{Ky}>1)$, 'proportionally sensitive' $(\mathrm{Ky}=1)$ and 'little sensitive' $(\mathrm{Ky}<1)$.

\section{RESULTS AND DISCUSSION}

The regression analysis of variance showed significant influence of water depths on the number of fruits per plant, equatorial diameter, fresh fruit weight, commercial productivity and soluble solids (Table 2). These variables presented the quadratic variation pattern validated by the determination coefficient using the Student's t-test (Figure 2).

The highest amount of fruits produced (1.46 per plant) was estimated at the maximum point with total water depth of $172.7 \mathrm{~mm}$ or $107.2 \%$ ETc (Figure $2 \mathrm{~A})$. The remaining water depths, corresponding to $25 \%, 50 \%, 75 \%, 100 \%, 125 \%$ and $150 \%$ ETc treatments, reduced this value by $49.2 \% ; 23.8 \%$; $7.5 \% ; 0.4 \% ; 2.3 \%$; and $13.4 \%$, respectively.

In qualitative terms, the optimization of equatorial diameter $(16.4 \mathrm{~cm})$, fresh fruit weight $(2.3 \mathrm{~kg})$ and soluble solids (12.1 ${ }^{\circ}$ Brix) of fruits was calculated at the maximum point with the respective total water depths of $136.6 \mathrm{~mm}(84.7 \% \mathrm{ETc}), 152.6$ $\mathrm{mm}(94.7 \% \mathrm{ETc})$ and $139.5 \mathrm{~mm}(86.6 \% \mathrm{ETc})$ (Figure $2 \mathrm{~B}, 2 \mathrm{C}$ and $2 \mathrm{D})$. The relative reductions caused by $25 \%, 50 \%, 75 \%, 100 \%, 125 \%$ and $150 \%$ ETc treatments were, in that order, $10.4 \% ; 3.5 \% ; 0.3 \%$; $0.7 \% ; 4.7 \%$; and $12.4 \%$ in equatorial diameter, $30.4 \% ; 12.5 \% ; 2.4 \% ; 0.2 \% ; 5.7 \%$; and $19.1 \%$ in fresh fruit weight and $18.6 \% ; 6.5 \% ; 0.7 \% ; 0.9 \%$; $7.2 \%$; and $19.7 \%$ in soluble solids.

The commercial yield was maximized (32.2
$\mathrm{Mg} \mathrm{ha}^{-1}$ ) with $161.6 \mathrm{~mm}(100.3 \% \mathrm{ETc})$ (Figure $2 \mathrm{E})$. With $25 \%, 50 \%, 75 \%, 100 \%, 125 \%$ and $150 \%$ ETc treatments, this value was reduced by $64.6 \%$; $28.8 \% ; 7.3 \% ; 0.0 \% ; 6.9 \%$; and $28.1 \%$, respectively. Considering commercial productivity as the most economically important variable, it could be said that the total water depth of $161.6 \mathrm{~mm}$ was the most adequate for irrigation management without water restriction. Using equations in Figure 2, the commercial fruit yield is estimated at $32.2 \mathrm{Mg} \mathrm{ha}^{-1}$ and the number of fruits per plant is estimated at 1.46 , with equatorial diameter of $16.3 \mathrm{~cm}$, fresh weight of $2.3 \mathrm{~kg}$ and soluble solids of $12.0^{\circ}$ Brix. These characteristics, especially in relation to width and fresh weight of fruits, indicate their commercialization preferably in the domestic market.

The quadratic response of variables followed the biological logic, that is, from the smallest water depth to the maximum water requirement, the variables evaluated increased in value at positive rates but gradually decreased, reaching the zero rate at the maximum point. From there, with water depths higher than the optimum, the variables decreased at negative rates. In terms of magnitude, variables were more negatively affected by $25 \%$ and $150 \%$ ETc treatments, which should have enhanced the detrimental effects of the water deficit $(25 \%$ ETc treatment) and excess water (150\% ETc treatment). These effects, considering the low water availability capacity and the high infiltration rate of red-yellow argisols (OTTONI FILHO, 2003), may have been direct in water deficit conditions, rapidly reducing the water availability in the root zone of plants, and indirect in excess water condition, increasing nutrient leaching below roots (Figure 3).

Figure 3 showed that the water depths of treatment with the highest water deficit, $25 \% \mathrm{ETc}$, were not sufficient to restore AFD. In this condition, according to Allen et al. (2006), the plant undergoes stress because its absorption occurs at rates lower than those of the transpirational demand. Under this type of stress, the morphological processes of yellow melon are impaired (PEREIRA FILHO et al., 2015), compromising production (SUASSUNA et al., 2011). In 50\% ETc treatment, the irrigation levels also affected the crop; however, in a slightly less severe way, because in only a few periods, the water applied did not replace AFD. This lower severity of the deleterious effects was more evident in $75 \%$ ETc treatment, since the water depths applied were almost always sufficient to restore AFD.

The complete replenishment of the water required by the crop, with $100 \% \mathrm{ETc}$, was responsible for the best soil water conditions, since in almost all 
days, water depths were close to the upper limit of AFD, in this case, the field capacity. Santos et al. (2013) explain that, in the field capacity, reducing the energy expenditure of plants with water absorption avoids reductions in production.

Water depths of $125 \%$ and mainly $150 \%$ ETc treatments exceeded the field capacity during most of the experimental phase. In order to allow the drainage of excess water by gravity (Alen et al., 2006) in sandy soil, may have favored the leaching of nutrients (ZENG et al., 2014), especially in weekly fertigation intervals. The adoption of high water depths in prolonged irrigation, with peaks over eight hours, should be cautious when fruits are not protected. In this work, some fruits that were close to emitters, those that presented rot, were not considered marketable, and were not included in the analyses.

According to results, it could be inferred that, if water is not a limiting factor, irrigation must fully restore the water needs of the crop to maximize commercial productivity. If otherwise, due to the occurrence of draughts, water must be supplied in a deficit way in order to optimize the water use efficiency and maintain production sustainability.

In the present work, this efficiency presented a cubic pattern with treatments (Figure 4).

The EUA maximization, estimated at 0.29 $\mathrm{Mg} \mathrm{ha}^{-1} \mathrm{~mm}^{-1}$ with $72.9 \mathrm{~mm}$ water $(45.2 \% \mathrm{ETc})$, was not interesting for the crop, as it reduced the maximum commercial yield by $34.6 \%$. EUA values of $25 \%$ and $50 \%$ ETc treatments, although high, were also not convenient, since they substantially reduced the optimum yield of the crop.

The adoption of a more moderate water deficit, such as $75 \%$ ETc treatment, was the most advantageous, since this treatment, in addition to having provided high water use efficiency, caused the lowest reduction in maximum productivity. This indicates that the strategy of deficient irrigation in the productive phase with $75 \%$ ETc could be used daily in yellow melon with minimal impacts on production. In this regard, Ahmadi-Mirabad et al. (2014) and Al-Mefleh et al. (2012) have shown that deficit irrigations with $80 \%$ and $75 \% \mathrm{ETc}$, respectively, can be statistically compared to irrigations with $100 \%$ ETc.

In a condition of moderate stress, yellow melon can present a certain morphophysiological dynamism (reduction of transpiration and root expansion, e.g.) to adapt to water scarcity (KUSVURAN, 2012; SHARMA et al., 2014). However, under extreme conditions, this adaptation may be limited by the scarcity of water availability. This could explain the drastic reduction of production with $25 \%$ ETc and the less severe reduction with 50\% and, in particular, $75 \%$ ETc.

According to Table 3, the decrease in commercial yield of yellow melon was less than proportional to the decrease in water use, since all Ky values were less than 1 .

Ky values of $75 \%, 50 \%$ and $25 \%$ ETc treatments were $48 \%, 39 \%$ and $9 \%$ lower than the indicative limit of sensitivity. By mathematical optimization using linear regression $(\mathrm{Ky}=0.8)$, this reduction reached 20\% (Figure 5A).

In the deficit range recommended by FAO Bulletin 33, Ky values remained low (Table 4). The decrease in Ky value in the regression equation of Figure 5B was 33\% greater than that of Figure 5A, because the treatment that most negatively affected the culture $(25 \% \mathrm{ETc})$ was neglected.

The results obtained and estimated in this work by treatment or by linear regression, have indicated that the crop is tolerant ('low sensitive' or 'little sensitive') to prolonged daily irrigations with controlled reduction of water supply $(\mathrm{Ky}<1)$ (DOORENBOS; KASSAM, 1979; STEDUTO et al. 2012). As explained by Lovelli et al. (2007), plants that present reduced Ky restrict less their yield with water stress due to the greater water use efficiency (Figure 3). Other experiments carried out under similar (LEITE et al., 2014) and different conditions (SIMSEK, COMLEKCIOGLU, 2011), confirm, due to the reduced Ky values, the high tolerance of yellow melon to water scarcity. 
TABLE 1 - Total effective rainfall, adopted effective rainfall, liquid irrigation layer and total water depth in each treatment at the productive phase (Phenological Phases III and IV) of hybrid 'Gold Mine' yellow melon.

\begin{tabular}{ccccccc}
\hline Treatment & $25 \%$ ETc & $50 \%$ ETc & $75 \%$ ETc & $100 \%$ ETc & $125 \%$ ETc & $150 \%$ ETc \\
\hline Total effective rainfall $(\mathrm{mm})$ & 32.00 & 32.00 & 32.00 & 32.00 & 32.00 & 32.00 \\
Adopted effective rainfall $(\mathrm{mm})$ & 11.15 & 17.78 & 20.64 & 22.11 & 23.59 & 25.06 \\
\hline Liquid irrigation layer $(\mathrm{mm})$ & 29.14 & 62.80 & 100.22 & 139.04 & 177.85 & 216.7 \\
\hline Total water depth $(\mathrm{mm})$ & 40.29 & 80.58 & 120.86 & 161.15 & 201.44 & 241.73 \\
\hline
\end{tabular}

ETc: crop evapotranspiration.

TABLE 2 - Summary of the regression analysis of variables of hybrid 'Gold Mine' yellow melon fruits.

\begin{tabular}{cccccccccc}
\hline \multirow{2}{*}{ Variation factors } & \multirow{2}{*}{ DF } & \multicolumn{1}{c}{ Mean square } \\
\cline { 3 - 10 } & & NF & DP & DE & MF & CP & EC & EP & SS \\
\hline Treatment & 5 & $0.07^{* *}$ & $1.40^{\text {n.s. }}$ & $3.07^{*}$ & $0.34^{* *}$ & $247.7^{* *}$ & $0.03^{\text {n.s. }}$ & $0.21^{\text {n.s. }}$ & $7.18^{* *}$ \\
Block & 3 & $0.01^{\text {n.s. }}$ & $1.97^{*}$ & $0.69^{\text {n.s. }}$ & $0.05^{\text {n.s. }}$ & $6.52^{\text {n.s. }}$ & $0.01^{\text {n.s. }}$ & $0.01^{\text {n.s. }}$ & $0.83^{\text {n.s. }}$ \\
Residue & 15 & 0.005 & 0.52 & 1.65 & 0.04 & 4.06 & 0.01 & 0.09 & 0.42 \\
Total & 23 & - & - & - & - & - & - & - & - \\
Variation coefficient $(\%)$ & - & 6.67 & 4.29 & 6.05 & 12.82 & 8.10 & 11.19 & 10.88 & 5.94 \\
\hline Linear model & 1 & $0.18^{* *}$ & - & $0.28^{\text {n.s. }}$ & $0.20^{\text {n.s. }}$ & $383.54^{* *}$ & - & - & $1.62^{\text {n.s. }}$ \\
Quadratic model & 1 & $0.16^{* *}$ & - & $13.3^{* *}$ & $1.33^{* *}$ & $782.66^{* *}$ & - & - & $29.4^{* *}$ \\
\hline
\end{tabular}

NF: number of fruits per plant (data transformed into square root); DP and DE: polar and equatorial diameters; MF: fresh fruit weight; PC: commercial productivity; EC and PE: skin and pulp thickness; SS: soluble solids.

GL: degrees of freedom; n.s. Not significant at $5 \%$ by the $\mathrm{F}$ test; ** significant at $1 \%$ by the $\mathrm{F}$ test; * Significant at $5 \%$ by the $\mathrm{F}$ test.

TABLE 3 - Actual evapotranspiration (ETr), maximum evapotranspiration (ETm), relative evapotranspiration deficit (1 - ETr / ETm), actual yield (Yr), maximum yield (Ym), relative yield decline (1 - Yr / Ym) and crop response factor to water deficit (Ky) of hybrid 'Gold Mine' yellow melon during the productive phase (phenological stages III and IV).

\begin{tabular}{cccccccc}
\hline Treatment & $\mathrm{ETr}(\mathrm{mm})$ & $\mathrm{ETm}(\mathrm{mm})$ & $(1-\mathrm{ETr} / \mathrm{ETm})$ & $\mathrm{Yr}\left(\mathrm{Mg} \mathrm{ha}^{-1}\right)$ & $\mathrm{Ym}\left(\mathrm{Mg} \mathrm{ha}^{-1}\right)$ & $(1-\mathrm{Yr} / \mathrm{Ym})$ & $\mathrm{Ky}$ \\
\hline $25 \% \mathrm{ETc}$ & 49.29 & 161.15 & 0.75 & 10.81 & 34.08 & 0.68 & 0.91 \\
$50 \%$ ETc & 80.58 & 161.15 & 0.50 & 23.64 & 34.08 & 0.31 & 0.61 \\
$75 \%$ ETc & 120.86 & 161.15 & 0.25 & 29.62 & 34.08 & 0.13 & 0.52 \\
\hline
\end{tabular}

ETc: crop evapotranspiration.

TABLE 4 - Estimated actual evapotranspiration values (ETr), maximum evapotranspiration (ETm), relative evapotranspiration deficit (1 - ETr / ETm), actual yield (Yr), maximum yield (Ym), relative yield decline / Ym) and water deficit response factor (Ky) of hybrid 'Gold Mine' yellow melon in the productive phase (phenological phases III and IV).

\begin{tabular}{cccccccc}
\hline Treatment & $\mathrm{ETr}(\mathrm{mm})$ & $\mathrm{ETm}(\mathrm{mm})$ & $(1-\mathrm{ETr} / \mathrm{ETm})$ & $\mathrm{Yr}\left(\mathrm{Mg} \mathrm{ha}^{-1}\right)$ & $\mathrm{Ym}\left(\mathrm{Mg} \mathrm{ha}^{-1}\right)$ & $(1-\mathrm{Yr} / \mathrm{Ym})$ & $\mathrm{Ky}$ \\
\hline $50 \% \mathrm{ETc}$ & 80.58 & 161.65 & 0.50 & 22.89 & 32.16 & 0.29 & 0.58 \\
$60 \% \mathrm{ETc}$ & 96.69 & 161.65 & 0.40 & 26.21 & 32.16 & 0.19 & 0.46 \\
$70 \% \mathrm{ETc}$ & 112.81 & 161.65 & 0.30 & 28.80 & 32.16 & 0.10 & 0.35 \\
$80 \% \mathrm{ETc}$ & 128.92 & 161.65 & 0.20 & 30.65 & 32.16 & 0.05 & 0.23 \\
$90 \% \mathrm{ETc}$ & 145.04 & 161.65 & 0.10 & 31.77 & 32.16 & 0.01 & 0.12 \\
\hline
\end{tabular}

ETc: crop evapotranspiration. 


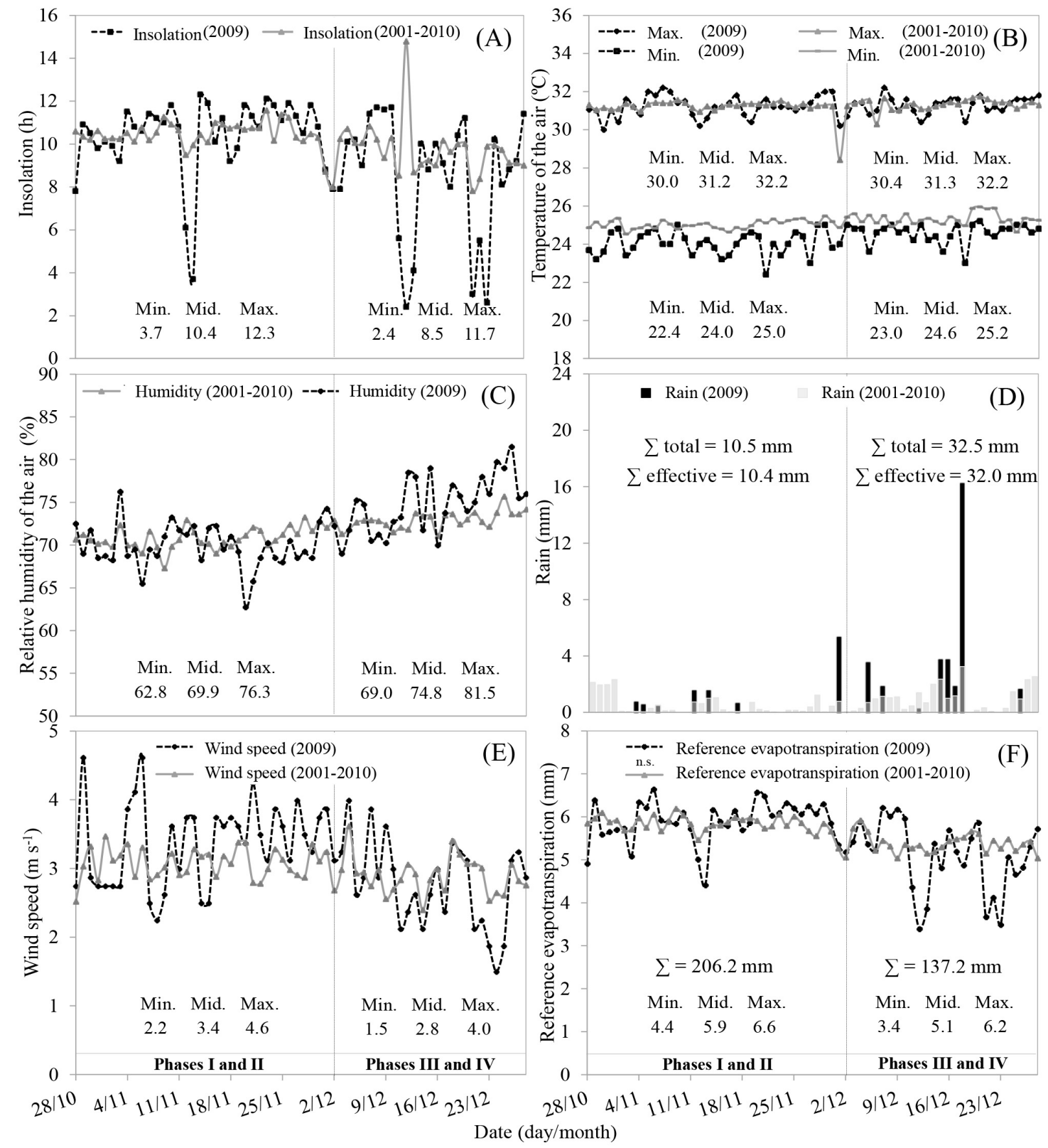

FIGURE 1 - Daily average values for one cycle of hybrid 'Gold Mine' yellow melon cultivation in 2009 and in the last 10 years (2001-2010): insolation (A), maximum and minimum air temperatures (B), relative air humidity (C), rainfall (D), wind speed (E) and Penman-Monteith reference evapotranspiration (F).

n.s.: the daily reference evapotranspiration values of 2009, statistically compared with the daily mean values of the 2001-2010 series, did not differ significantly at $5 \%$ by the Student's t test. Source: Meteorological Station of the Federal University of Ceará. 

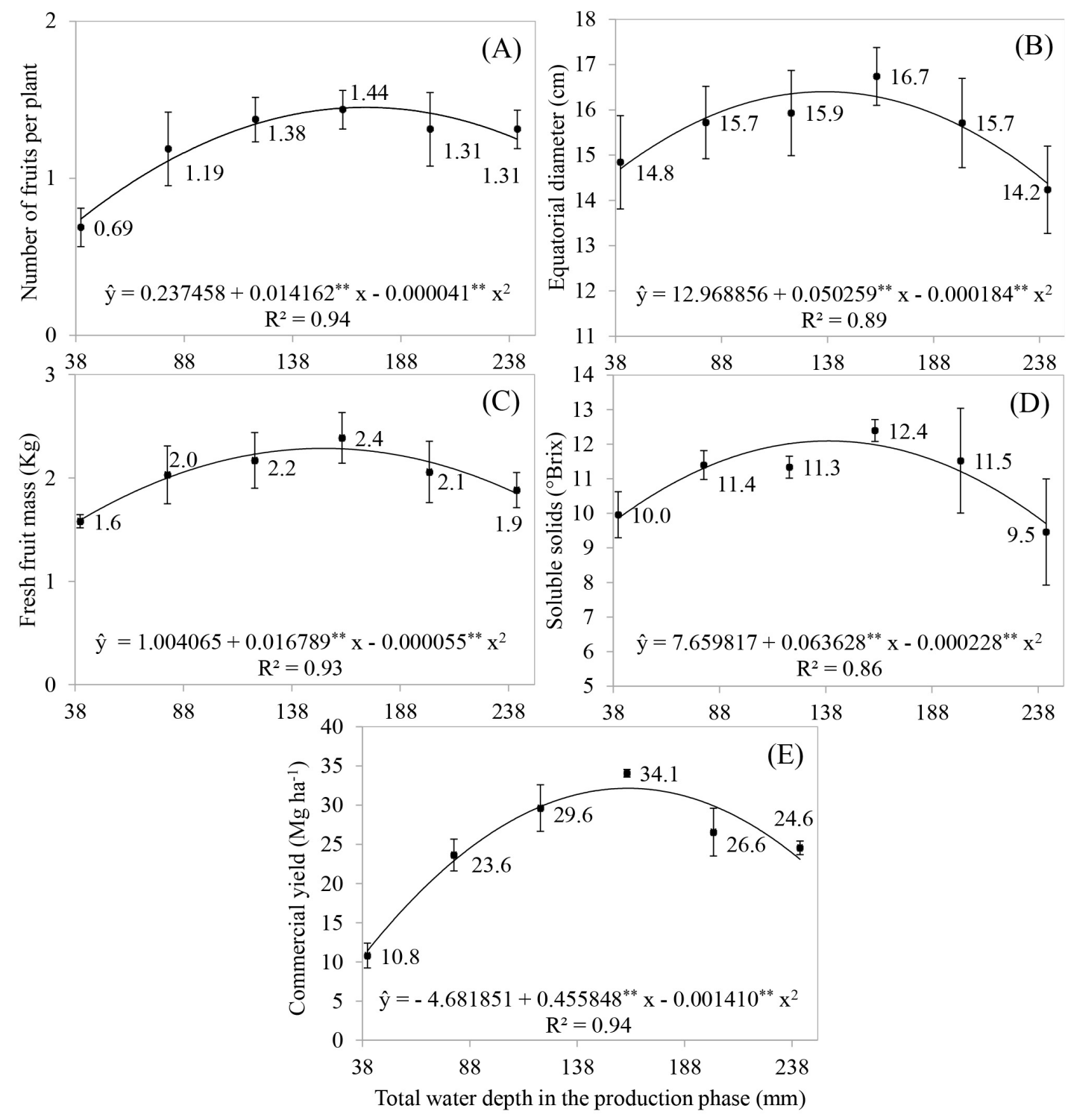

FIGURE 2 - Number of fruits per plant (A), equatorial diameter (B), fruit fresh weight (C), soluble solids (D), and commercial productivity (E) of hybrid 'Gold Mine' yellow melon as a function of water depth $(25 \%, 50 \%, 75 \%, 100 \%, 125 \%$ and $150 \%$ of crop evapotranspiration).

** significant at $1 \%$ by Student's t-test. Confidence interval $\pm 95 \%$. 


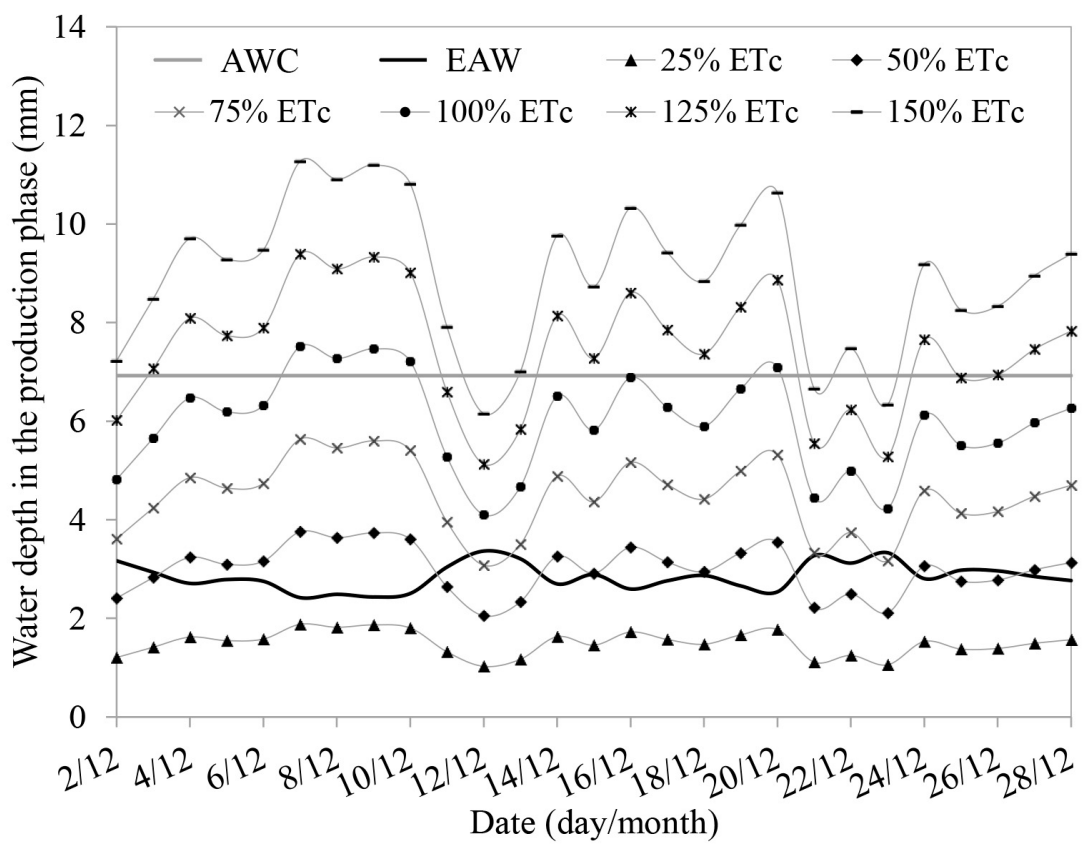

FIGURE 3 - Total water depth (liquid water depth and effective precipitation) of 25\%, 50\%, 75\%, 100\%, $125 \%$ and $150 \%$ ETc treatments in the productive phase (phenological phases III and IV) of hybrid 'Gold Mine' yellow melon compared to the water availability capacity $(\mathrm{CAD}=6.92 \mathrm{~mm})$ in soil and readily available water (AFD) recommended by Allen et al. (2006).

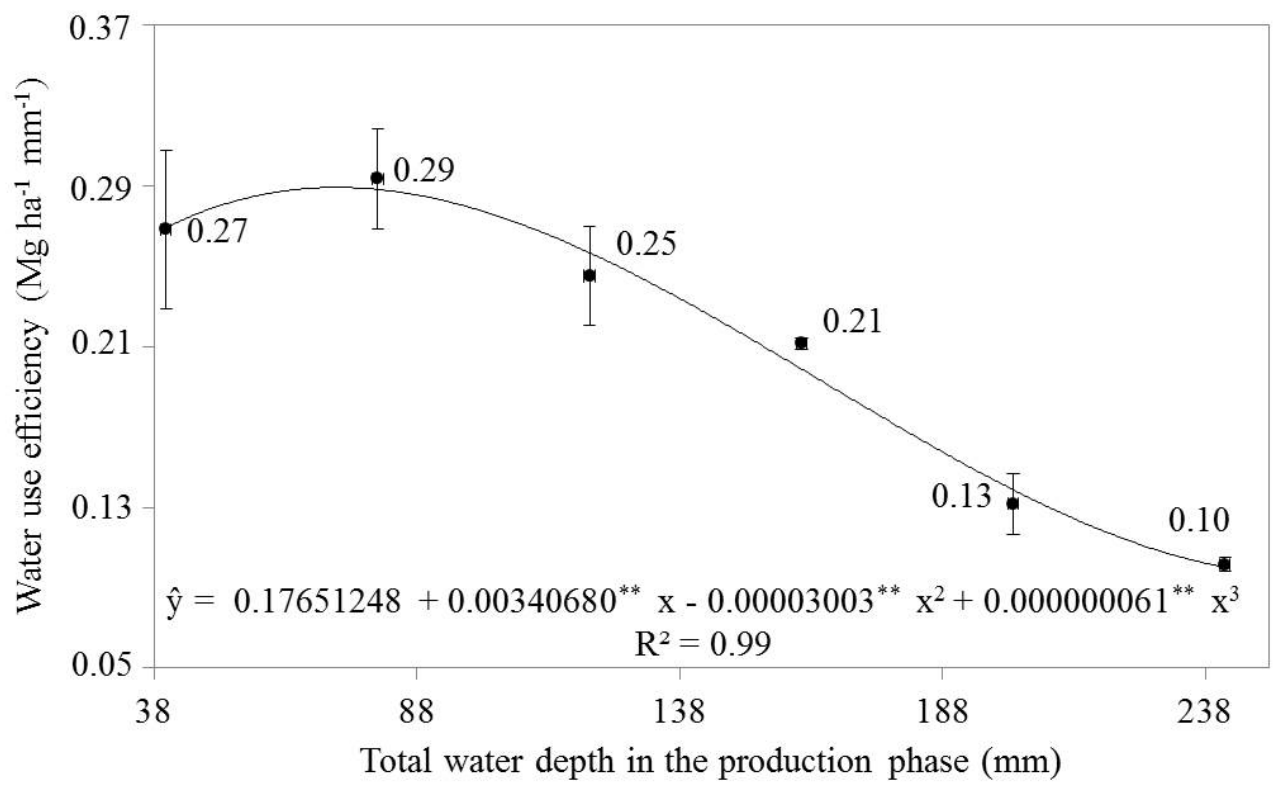

FIGURE 4 - Water use efficiency of hybrid 'Gold Mine' yellow melon in the productive phase (phenological phases III and IV) as a function of the total water depth (liquid water depth and effective precipitation) of $25 \%, 50 \%, 75 \%, 100 \%, 125 \%$ and $150 \%$ ETc treatments.

** significant at $1 \%$ by Student's t-test. Confidence interval $\pm 95 \%$. 


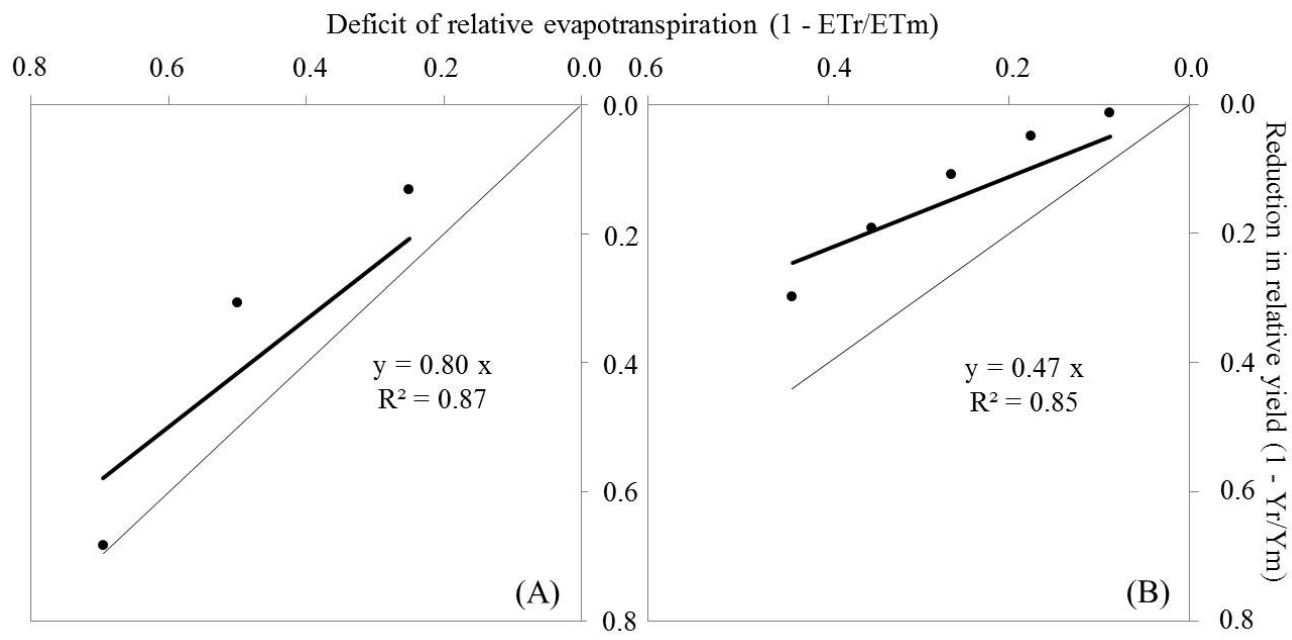

FIGURE 5 - Response factor to water deficit (Ky) of hybrid 'Gold Mine' yellow melon in the productive phase (phenological phases III and IV), for treatments with $25 \%, 50 \%$ and $75 \%$ ETc (A) and estimated at 50\%, 60\%, 70\%, 80\% and 90\% ETc (B). ETc: crop evapotranspiration.

\section{CONCLUSIONS}

With no restriction to water application, yellow melon cultivated under the edaphoclimatic conditions of the coast of Ceará can be irrigated daily by low-flow drip tape with full replenishment of ETc in the productive phase to maximize fruit production.

If there is water use restriction and for being tolerant to water deficiency in the productive phase $(\mathrm{Ky}<1)$, daily irrigation strategies with controlled water deficit can be used.

\section{ACKNOWLEDGMENTS}

To the National Council for Scientific and Technological Development (CNPq), for financing the project and granting of scholarships.

\section{REFERENCES}

AHMADI-MIRABAD, A.; LOTFI, M.; ROOZBAN, M.R. Growth, yield, yield components and water-use efficiency in irrigated cantaloupes under full and deficit irrigation. Electronic Journal of Biology, Bielefeld, v.10, n.3, p.79-84, 2014.
ALI, M.H.; HOQUE, M.R.; HASSAN, A.A.; KHAIR, A. Effects of deficit irrigation on yield, water productivity, and economic returns of wheat. Agricultural Water Management, Amsterdam, v.92, n.3, p.151-161, 2007.

ALLEN, R.G.; PEREIRA, L.S.; RAES, D.; SMITH, M. Evapotranspiración del cultivo: guías para la determinación de los requerimientos de agua de los cultivos. Roma: Organización de las Naciones Unidas para la Agricultura y la Alimentación, 2006. 300 p. (Estudio FAO Riego y Drenaje, 56).

AL-MEFLEH, N.K.; SAMARAH, N.; ZAITOUN, S.; AL-GHZAWI, A. A. M. Effect of irrigation levels on fruit characteristics, total fruit yield and water use efficiency of melon under drip irrigation system. Journal of Food, Agriculture and Environment, Helsinki, v.10, n.2, p.540-545, 2012.

BAHADUR, A., CHATTERJEE, A., KUMAR, R., SINGH, M., NAIK, P. Physiological and biochemical basis of drought tolerance in vegetables. Vegetable Science, Jakhini, v.38, n.1, p.1-16, 2011.

BILIBIO, C.C.; JACINTO, A.C.; MARTINS, M.; REZENDE, F.C.; FREITAS, E.A.; GOMES, L.A.A. Desenvolvimento vegetativo e produtivo da berinjela submetida a diferentes tensões de água no solo. Revista Brasileira de Engenharia Agrícola e Ambiental, Campina Grande, v.14, n.7, p.730-735, 2010 . 
CAMPELO, A.R.; AZEVEDO, B.M. de; NASCIMENTO NETO, J.R. do; VIANA, T.V. de A.; PINHEIRO NETO, L.G.; LIMA, R.H. Manejo da cultura do melão submetida a frequências de irrigação e fertirrigação com nitrogênio. Horticultura Brasileira, Brasília, v.32, n.2, p.138-144, 2014.

CAVALCANTI, N.M. da S.; DUTRA, A.F.; MELO, A.S. de; SILVA, F.G. da; DUTRA, W.F.; NUNES JUNIOR, E. da S. Aspectos agronômicos do meloeiro 'Mandacaru' cultivado em ambiente protegido sob irrigação. Irriga, Botucatu, v.20, n.2, p.261-272, 2015.

DOGAN, E.; KIRNAK, E.H.; BEREKATOGLU, E.K.; BILGEL, E.L.; SURUCU, E.A. Water stress imposed on muskmelon (Cucumis melo L.) with subsurface and surface drip irrigation systems under semi-arid climatic conditions. Irrigation Science, New York, v.26, n.2, p.131-138, 2008.

DOORENBOS, J.; KASSAM, A.H. Yield response to water. Rome: Food and Agriculture Organization of the United Nations, 1979. 257 p. (Irrigation and Drainage Paper, 33).

FIGUEIRÊDO, M.C.B. de; BOER, I.J. de; KROEZE, C.; BARROS, V. da S.; SOUSA, J.A. de; ARAGÃO, F.A.S. de; POTTING, J. Reducing the impact of irrigated crops on freshwater availability: the case of Brazilian yellow melons. The International Journal of Life Cycle Assessment, New York, v.19, n.2, p.437-448, 2014.

KELLER, J.; KARMELI, D. Trickle irrigation design parameters. Transactions of the ASAE, St. Joseph, v.17, p.678-684, 1974

KUSVURAN, S. Effects of drought and salt stresses on growth, stomatal conductance, leaf water and osmotic potentials of melon genotypes (Cucumis melo L.). African Journal of Agricultural Research, Nigeria, v.7, n.5, p.775-781, 2012.

LEITE, K. N.; CABELLO, M. J.; VALNIR JÚNIOR, M.; TARJUELO, J. M.; DOMÍNGUEZ, A. Modelling sustainable salt water management under deficit irrigation conditions for melon in Spain and Brazil. Journal of the Science of Food and Agriculture, Oxford, v.95, p.2307-2318, 2014.
LOVELLI, S.; PERNIOLA, M.; FERRARA, A.; DI TOMMASO, T. Yield response factor to water $(\mathrm{Ky})$ and water use efficiency of Carthamus tinctorius L. and Solanum melongena L. Agricultural Water Management, Amsterdam, v.92, n.1, p.73-80, 2007.

MANI, F. Evaluation of drought stress on yield and physiological attributes in Cantaloupe crop (Cucumis melo L.). Agriculture, Sousse, v.4, n.12, p.6-10, 2014.

MIORINI, T.J.J.; SAAD, J.C.C.; MENEGALE, M.L. Supressão de água em diferentes fases fenológicas do feijoeiro (Phaseolus vulgaris L.). Irriga, Botucatu, v.16, n.4, p.360-368, 2011.

MIRANDA, F.R. de; BLEICHER, E. Evapotranspiração e coeficientes de cultivo e de irrigação para a cultura do melão (Cucumis melo L.) na região litorânea do Ceará. Fortaleza: Embrapa Agroindústria Tropical, 2001. 17 p.

OTTONI FILHO, T. Uma classificação físico-hídrica dos solos. Revista Brasileira de Ciência do Solo, Viçosa, MG, v.27, n.2, p.211-222, 2003.

PEREIRA FILHO, J.V.; BEZERRA, F.M.L.; CHAGAS, K.L.; SILVA, T.C. da; Pereira, C.C.M. de S. Trocas gasosas e fitomassa seca da cultura do meloeiro irrigado por gotejamento nas condições semiáridas do Nordeste. Revista Brasileira de Agricultura Irrigada, Fortaleza, v.9, n.3, p.171$182,2015$.

PEREIRA FILHO, J.V.; BEZERRA, F.M.L.; SILVA, A.R.A.; SOUSA, C.C.M. de; CASTRO, J.M. de. Frequência de irrigação e aplicação de $\mathrm{N}$ em meloeiro irrigado por gotejamento nas condições semiáridas do Nordeste. Científica, Jaboticabal, v.42, n.1, p.1122, 2014.

PIRES, M.M.M.L.; SANTOS, H.A.; SANTOS, D.F.; VASCONCELOS, A.S.; ARAGÃO, C.A.Produção do meloeiro submetido a diferentes manejos de água com o uso de manta de tecido não tecido. Horticultura Brasileira, Brasília, DF, v.31, n.2, p.304-310, 2013. 
SANTOS, C.S. dos; SILVA, P.F. da; SANTOS, J.C.C.dos; SILVA, C.H. da; BARROS, A.C. Estimativa da umidade na capacidade de campo em vasos e em laboratório. Revista Verde de Agroecologia e Desenvolvimento Sustentável, Pombal, v.8, n.2, p.151-160, 2013.

SANTOS, H.G. dos; JACOMINE, P.K.T.; ANJOS, L.H.C. dos; OLIVEIRA, V.Á. de; COELHO, M.R.; LUMBRERAS, J.F.; CUNHA, T.J.F. (Ed.). Sistema brasileiro de classificação de solos. 2.ed. Rio de Janeiro: EMBRAPA-SPI, 2006. 306 p.

SHARMA, S.P.; LESKOVAR, D.I.; CROSBY, K.M.; VOLDER, A.; IBRAHIM, A.M. H. Root growth, yield, and fruit quality responses of reticulatus and inodorus melons (Cucumis melo L.) to deficit subsurface drip irrigation.Agricultural Water Management, Amsterdam, v.136, p.75-85, 2014.

SILVA, A.R.A. da; BEZERRA, F.M.L.; FREITAS, C.A.S. de; AMORIM, A.V. de; CARVALHO, L.C.C.; PEREIRA FILHO, J.V. Coeficientes de sensibilidade ao déficit hídrico para a cultura do girassol nas condições do semiárido cearense. Revista Brasileira de Agricultura Irrigada, Fortaleza, v.8, n.1, p.38$51,2014$.

SIMSEK, M.; COMLEKCIOGLU, N. Effects of different irrigation regimes and nitrogen levels on yield and quality of melon (Cucumis melo L.). African Journal of Biotechnology, Lagos, v.10, n.49, p.10009-10018, 2011.
SMITH, M. Cropwat: a computer program for irrigation planning and management. Rome: Food and Agriculture Organization of the United Nations, 1992. $126 \mathrm{p}$.

STEDUTO, P.; HSIAO, T.C.; FERERES, E.; RAES, $D$. Crop yield response to water. Rome: Food and Agriculture Organization of the United Nations, 2012. 500 p.(Irrigation and Drainage Paper, 66).

SUASSUNA, J.F.; MELO, A.S.; COSTA, F.S.; FERNANDES, P.D.; FERREIRA, R.S.; SOUSA, M.S.S. Eficiência fotoquímica e produtividade de frutos de meloeiro cultivado sob diferentes lâminas de irrigação. Semina: Ciências Agrárias, Londrina, v.32, n.4, p.1251-1262, 2011.

VALNIR JÚNIOR, M.; LIMA, V.L.A. de; GOMES FILHO, R.R.; CARVALHO, C.M. de; SOARES, F.A.L.; LIMA, S.C.R.V. Lâminas de irrigação e frequência de aplicação no crescimento do meloeiro. Revista Brasileira de Agricultura Irrigada, Fortaleza, v.7, n.1, p.42-53, 2013.

ZENG, W.; XU, C.; WU, J.; HUANG, J. Soil salt leaching under different irrigation regimes: HYDRUS-1D modelling and analysis. Journal of Arid Land, Xinjiang, v.6, n.1, p.44-58, 2014. 